\title{
Standardization of processing and storage techniques of Celastrus paniculatus Willd. (Malkangni) seeds for livelihood improvement
}

\author{
Saxena Hari Om妮, Pawar Ganesh and Sen Ruchi
}

Received: 12.02.2020

Revised: 19.03.2020

Accepted: 31.03.2020

\begin{abstract}
The present study dealt to standardize the post harvesting practices (drying, processing, suitable containers, storage duration) of Celastrus paniculatus seeds in terms of oil content which revealed the sun drying better in comparison to shade and oven drying to maintain quality of seeds. It is also recommended to wash the seeds in water before storage to remove the outer pulpy layer on the seeds which allows the infestation of saw-toothed grain beetle (Oryzaephilus surnemensis Linn.). Moreover, high density polythene (HDPE) bags, $4-5^{\circ} \mathrm{C}$ and duration of six months were found optimum for storage of Malkangni seeds in term of oil content.
\end{abstract}

Key words: Celastrus paniculatus, seeds, processing, storage containers, duration, oil content

\section{Introduction}

Processing and storage of medicinal produce play an important role in determining its quality. Bioactive constituents showed a rapid hydrolytic decomposition during storage. The magnitude of such degradation is significantly influenced by nature of collection, drying temperature treatments, processing and storage conditions (Karlund et al., 2014; Kalt et al., 1999; Ansari, 2011; Kokate, 2004). Improper drying and storage may make the materials susceptible towards the attack of mites, nematode worms, insects/moths, and beetles which can also destroy herbal drugs during storage (Kamboj, 2012). As per WHO guidelines, the medicinal plant produce must be stored under specified conditions in order to avoid contamination, deterioration and to enhance long term storage. Celastrus paniculatus Willd. is commonly known as Malkangni or Jyotishmati (family: Celastraceae) and is a threatened medicinal plant with woody climber reaching up to a height of $10 \mathrm{~m}$. It is found throughout India up to an altitude of $1200 \mathrm{~m}$, mainly in deciduous forests. Seeds of this species are of medicinal importance and are utilized in treatment of rheumatism, gout, neurological disorder and to improve memory (Nadkarni, 1976). Seed oil is reported to possess

\section{Author's Address}

NWFP Section, Silviculture, Forest Management and Agroforestry Division, Tropical Forest Research Institute, Jabalpur (M.P.) - 482021, India

E-mail.: hariomsaxena81@gmail.com sedative and anticonvulsant properties (Gatinode et al., 1957). It is beneficial to psychiatric patients (Hakim, 1964) and in increasing the intelligence quotient of mentally retarded children (Nalini et al., 1986). It is also useful in treating abdominal disorders, beriberi and sores. It is one of the high trade sourced medicinal plant species from tropical forests whose estimated annual trade is approximately 200 - 500 metric tons (Anonymous, 2020). The price of seeds varies from Rs. 200 - 350 per $\mathrm{kg}$ in various markets. The seeds of Malkangni are one of the commercially important NTFPs of central Indian region and are collected by the rural and tribal communities for earning their livelihood. Fruits of Malkangni are collected and processed by the dependent communities in unscientific manner due to absence of standardized post harvesting practices. The objective of the present study is to standardize the processing and storage techniques for seeds of $C$. paniculatus for better management and livelihood improvement.

\section{Material and Methods}

Collection of fruits of Malkangni: Mature fruits of Malkangni were collected from the forest areas of Chhindwara district of Madhya Pradesh in the months of November and brought to the laboratory for further processing. 
Processing of fruits of Malkangni: Seeds of Malkangni were separated from its fruits by removing petals manually or by rubbing lightly on the surface of jute bag/ rough surface. Seeds were washed in water to remove the outer pulpy layer on the seeds and dried in shade, sun and hot air at $40^{\circ} \mathrm{C}$ for $24 \mathrm{hrs}$. Time of drying was kept constant to observe the effect. Seeds dried by all methods were evaluated separately for oil content.

Determination of moisture content: Moisture content in samples was determined by loss of water in terms of percent $\mathrm{w} / \mathrm{w}$ using the formula:

Moisture content $=$ Fresh Weight - Dry weight $/$ Fresh Weight x 100

Storage of dried seeds of Malkangni in different containers: Dried seeds of Malkangni were stored separately in different containers i.e. HDPE bags, Woven sacks, Gunny bags, Markin cloth, Tin, Glass and Plastic containers in three replicates at room temperature. Unpacked samples kept in open environment were taken as control. Seeds of Malkangni were stored in different containers in the month of December and evaluated for the oil content. Seeds stored in HDPE bags were also kept at $4-5^{\circ} \mathrm{C}$ to examine the effect on oil content. The experiments were also repeated in the successive year.

Evaluation of oil content in Malkangni seeds stored in different containers: Seeds of Malkangni stored in different containers were evaluated for its oil content by Soxhlet apparatus at quarterly intervals for one year. $10 \mathrm{gm}$ of Malkangni seeds taken from a container were powdered. Powdered sample was extracted for oil with petroleum ether $\left(60-80^{\circ} \mathrm{C}\right)$ using soxhlet apparatus. The filtrate was concentrated using water bath and the yield $(\mathrm{v} / \mathrm{w})$ of the oil was calculated (Jadhav and Patwardhan, 2003).

\section{Statistical analysis}

The data were statistically analyzed. Experiments were carried out in triplicate and results expressed as Mean $\pm \mathrm{SD}(\mathrm{n}=3)$. ANOVA was applied to check the results as significant and non significant.

\section{Results and Discussion}

Effect of three different drying methods on oil content in Malkangni seeds is given in Table 1.

Drying of seeds in shade, sun and hot air oven $\left(40^{\circ}\right.$ C) for $24 \mathrm{hrs}$ reduced the moisture level up to $18.12 \%, 15.4 \%$ and $14.31 \%$ respectively. Results showed that the Malkangni seeds dried in sun contained maximum oil content (64\%) content. Washing of Malkagni seeds in water before storage is required to remove the outer pulpy layer on the seeds which leads their deterioration due to infestation of saw-toothed grain beetle (Oryzaephilus surnemensis Linn.) (Figure 1 and 2). Sun dried seeds of Malkangni stored in different containers were evaluated for oil content at quarterly intervals in the year 2014 and its successive year 2015 (Table 2 and 3). Table 4 showed the oil content evaluated in seeds stored in HDPE bags kept at $4-5^{\circ} \mathrm{C}$ in all quarters of both the years. The initial oil content in seeds at the time of storage was found as $64.61 \%$ and $64.8 \%$ in the years 2014 and 2015 respectively.

Table 1. Oil content in Malkangni seeds dried by different methods

\begin{tabular}{|c|c|c|c|c|c|c|}
\hline & Shade drying & Sun drying & Hot air drying at $40^{\circ} \mathrm{C}$ & \multirow{2}{*}{$\mathbf{S E} \pm$} & \multirow{2}{*}{$\begin{array}{l}\text { CD at } \\
5 \%\end{array}$} \\
\hline Celastrus & Time & 24 & 24 & 24 & & \\
\hline paniculatus & Moisture \% & 18.12 & 15.4 & 14.31 & 0.890 & N/A \\
\hline fruits & Oil \% & $60 \%$ & $64 \%$ & $63 \%$ & 0.424 & 1.495 \\
\hline
\end{tabular}



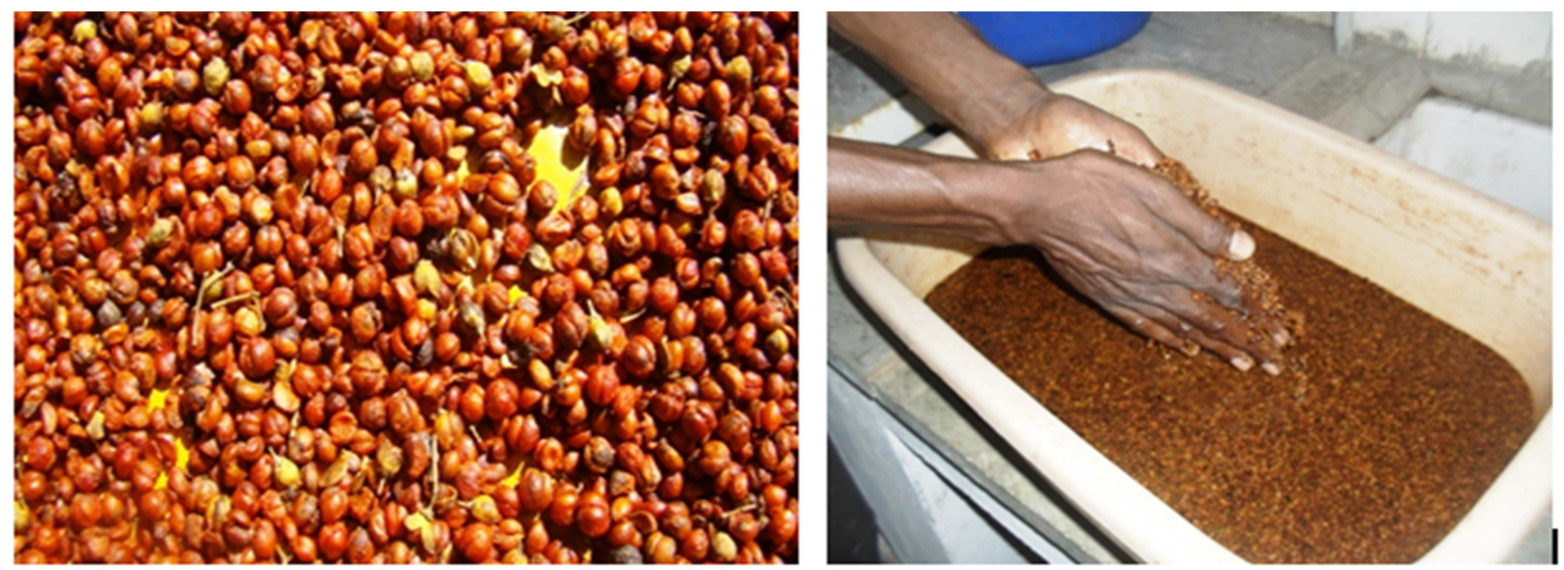

Figure 1. Processing of Malkangni (Celastrus paniculatus) fruits
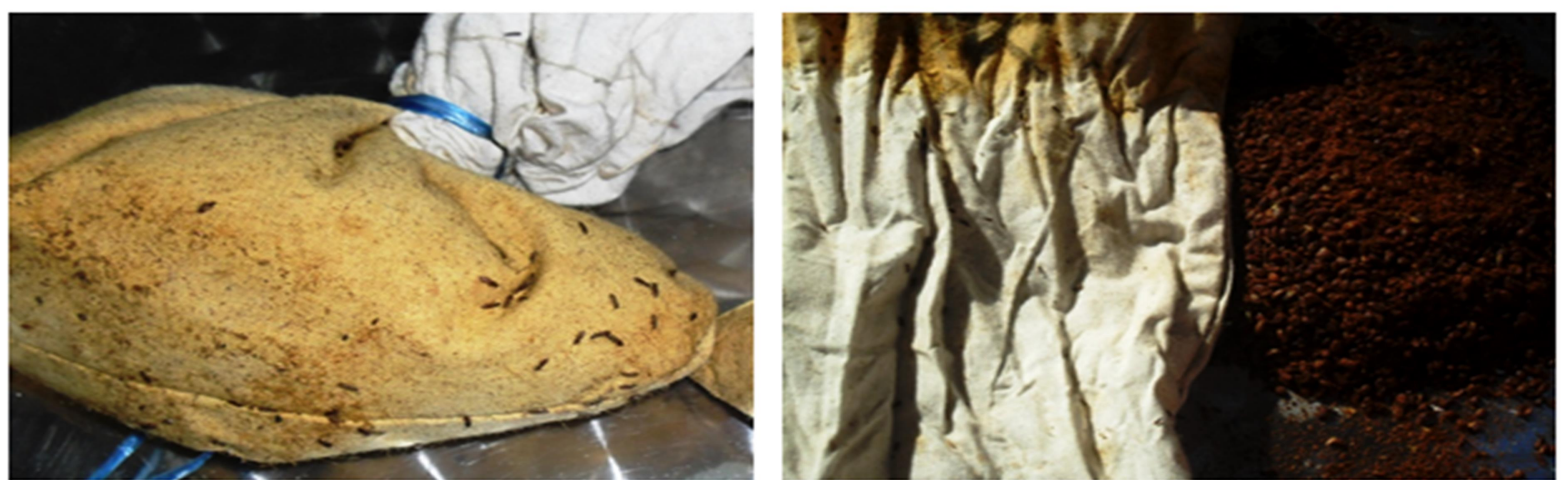

Figure 2. Infestation of Malkangni seeds with Saw-toothed grain beetle (Oryzaephilus surnemensis Linn.)

Table 2. Oil content in Malkangni seeds stored in different containers in the year 2014

\begin{tabular}{|c|c|c|c|c|}
\hline \multirow{2}{*}{ Containers } & \multicolumn{4}{|c|}{ Oil content (\%) } \\
\cline { 2 - 5 } & March, 2014 & June, 2014 & September, 2014 & December, 2014 \\
\hline HDPE bags & 61.87 & 54.80 & 54.37 & 53.53 \\
\hline Plastic & 63.30 & 55.53 & 54.45 & 54.07 \\
\hline Glass & 63.80 & 55.30 & 55.13 & 59.37 \\
\hline HDPE bags (4-5 ${ }^{\circ}$ C) & 64.60 & 64.35 & 61.59 & 52.33 \\
\hline Steel & 62.97 & 55.25 & 54.82 & 49.40 \\
\hline Tin & 62.81 & 52.26 & 51.53 & 48.16 \\
\hline Gunny bags & 59.40 & 51.07 & 50.20 & 48.15 \\
\hline Woven sacks & 62.13 & 51.60 & 50.47 & 47.67 \\
\hline Markin bags & 55.36 & 50.30 & 48.25 & 41.12 \\
\hline Open (control) & 58.37 & 48.80 & 42.11 & 0.685 \\
\hline CD at 5 \% & 0.908 & 0.785 & 1.092 & 0.230 \\
\hline \hline
\end{tabular}

119

Environment Conservation Journal 
Table 3. Oil content in Malkangni seeds stored in different containers in the year 2015

\begin{tabular}{|c|c|c|c|c|}
\hline \multirow{2}{*}{ Containers } & \multicolumn{4}{|c|}{ Oil content (\%) } \\
\hline & March, 2015 & June, 2015 & September, 2015 & December, 2015 \\
\hline HDPE bags & 61.95 & 55.0 & 54.40 & 53.80 \\
\hline Plastic & 63.46 & 55.6 & 54.20 & 53.20 \\
\hline Glass & 63.87 & 55.3 & 55.13 & 54.05 \\
\hline HDPE bags $\left(4-5^{\circ} \mathrm{C}\right)$ & 64.77 & 64.3 & 61.57 & 59.47 \\
\hline Steel & 62.90 & 55.3 & 54.80 & 52.33 \\
\hline Tin & 62.83 & 52.3 & 52.00 & 49.25 \\
\hline Gunny bags & 59.21 & 51.4 & 50.44 & 48.27 \\
\hline Woven sacks & 62.00 & 51.5 & 50.43 & 48.04 \\
\hline Markin bags & 55.52 & 50.0 & 48.13 & 47.76 \\
\hline Open (control) & 58.36 & 48.6 & 42.17 & 41.18 \\
\hline CD at $5 \%$ & 0.607 & 0.946 & 0.744 & 0.532 \\
\hline $\mathbf{S E} \pm$ & 0.204 & 0.318 & 0.251 & 0.179 \\
\hline
\end{tabular}

Table 4. Oil content in Malkangni seeds stored in HDPE bags $\left(4-5^{\circ} \mathrm{C}\right)$

\begin{tabular}{|c|c|c|}
\hline Quarters & Oil content (\%) & SE \pm \\
\hline March 2014 & 64.60 & 0.145 \\
\hline June 2014 & 64.35 & 0.177 \\
\hline September 2014 & 61.59 & 0.318 \\
\hline December 2014 & 59.37 & 0.291 \\
\hline March 2015 & 64.77 & 0.348 \\
\hline June 2015 & 64.3 & 0.236 \\
\hline September 2015 & 61.57 & 0.218 \\
\hline December 2015 & 59.47 & 0.219 \\
\hline CD at 5 \% & 0.764 & \\
\hline
\end{tabular}

Table 2 and 3 indicated the maximum oil content in in the oil content. The trend of decrease of oil seeds stored in HDPE bags kept at $4-5^{\circ} \mathrm{C}$ and content in different containers can be seen in Figure minimum oil content in seeds stored in Markin bags 3 and 4. HDPE bags was found the best containers in both the years 2014 and 2015. It was observed to keep Malkangni seeds at $4-5^{\circ} \mathrm{C}$ for 6 months. that the initial oil content was retained upto $2^{\text {nd }}$ The trend in oil content in seeds of Malkangni quarter in the seeds stored in HDPE bags kept at 4- seeds stored in HDPE bags kept at $4-5^{\circ} \mathrm{C}$ in $5^{\circ} \mathrm{C}$ in both the years while in case of seeds stored different quarters of both years can be seen in in other containers, there was continuously decrease Figure 5. 


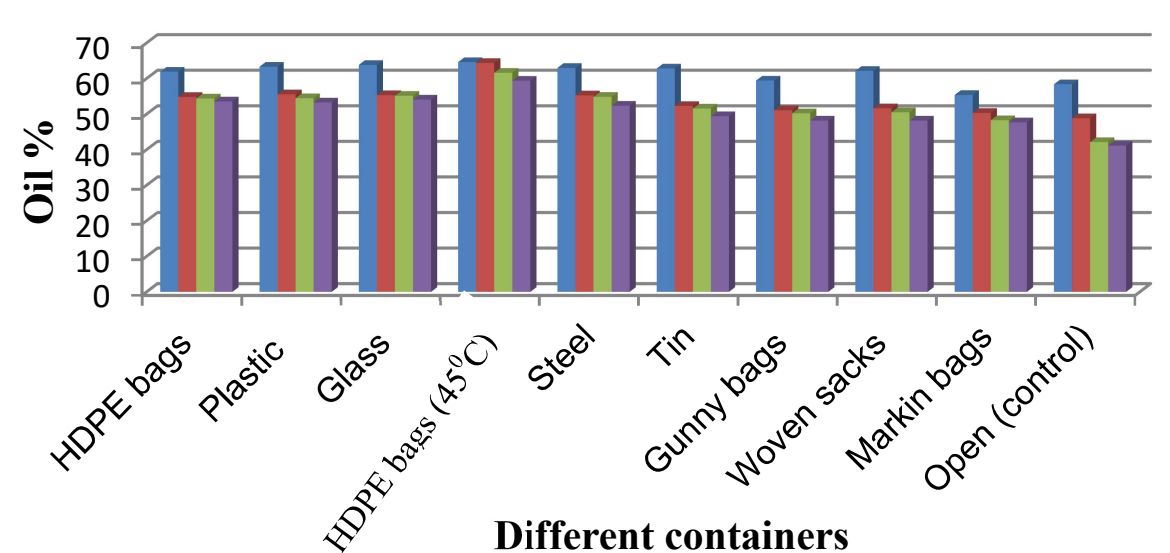

March, 2014

- June, 2014

September, 2014

- December, 2014

Figure 3. Oil content in Malkangni seeds stored in different containers (year 2014)

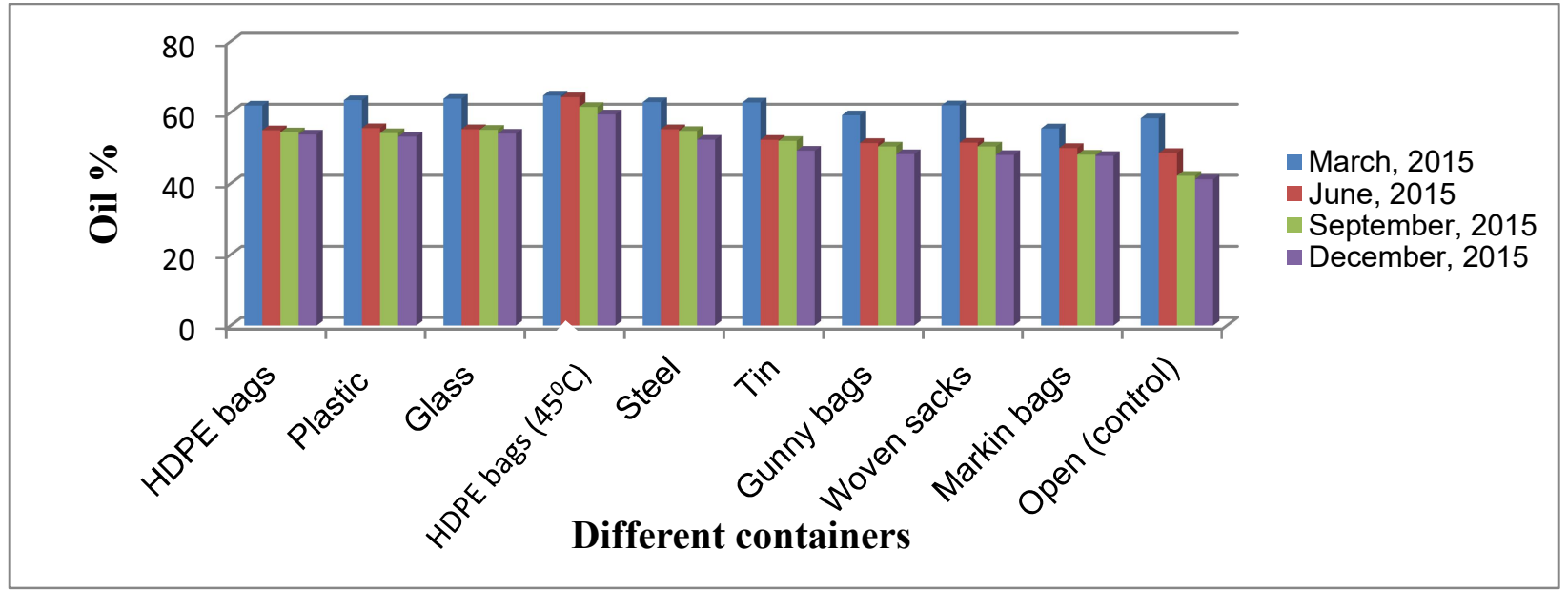

Figure 4. Oil content in Malkangni seeds stored in different containers (year 2015)

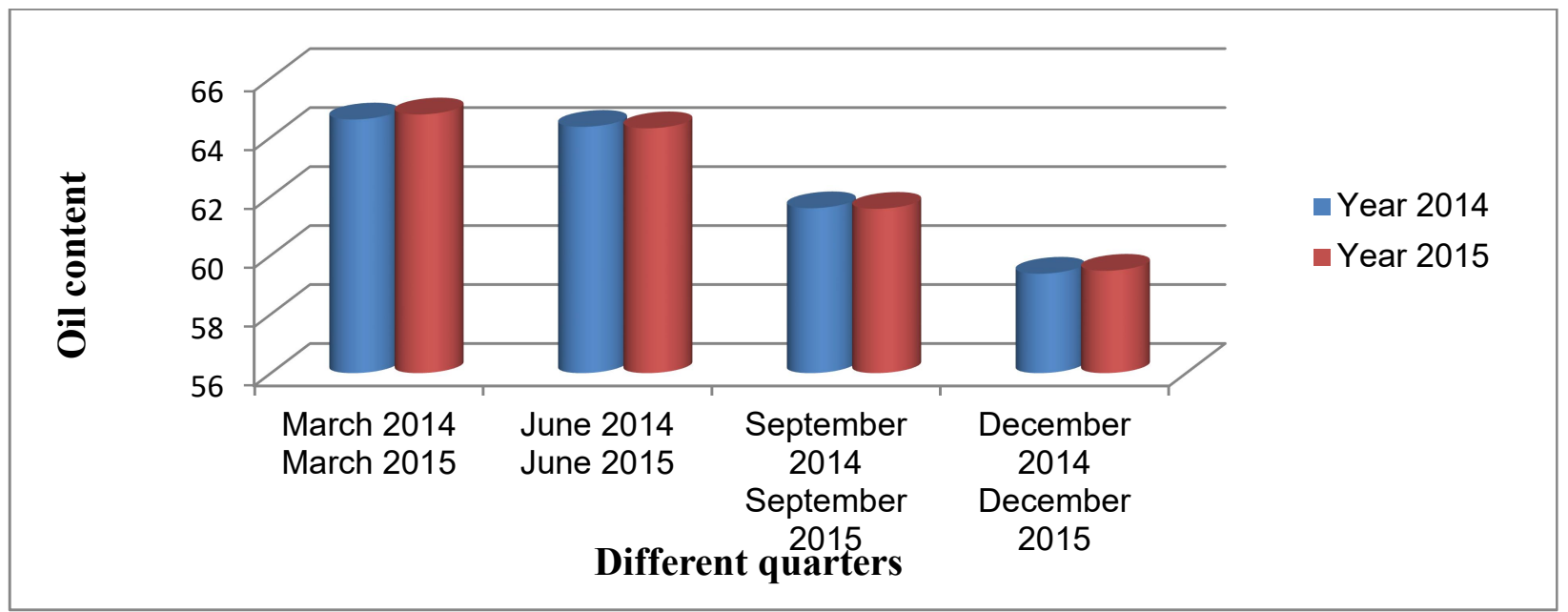

Figure 5. Oil content in Malkangni seeds stored in HDPE bags at 4-5 ${ }^{\circ} \mathrm{C}$ (years 2014 and 2015) 
Analysis of variance indicated significant $(\mathrm{P}<$ 0.05 ) variation in the oil content of seeds stored in different containers within the quarters as well as between the quarters in both the successive years. Similarly, significant $(\mathrm{P}<0.05)$ variation was also observed in oil content of Malkangni seeds stored in HDPE bags kept at $4-5^{\circ} \mathrm{C}$ after initial two quarters. The present study discovered the sun drying better in comparison to other drying methods. It may be due to the fact that in winter season due to low temperature, the drying of raw materials is slow and inefficient. Such conditions promote mould growth which results in deterioration of raw materials (Singh, 2008). Tanko et al., (2005) reported that natural drying promotes the removal of water from the material due to exposure to sun and desiccating effect of air currents. Another study revealed that natural airdrying is easy to control and rarely damages the crop (Downs and Compton, 1955). Downs and Compton (1955) also stated that the weather conditions limit the use of natural drying and it is a popular method especially in those areas where maturity and harvesting of the medicinal plants coincides with the beginning of the dry season, and their phytochemicals are not photosensitive.

The proper storage of medicinal plants is of utmost importance to maintain their quality, efficacy and oil content. The present investigation revealed that seeds stored in HDPE bags kept at $4-5^{\circ} \mathrm{C}$ contained maximum oil content followed by plastic and glass containers while minimum oil content was noted in the seeds stored in markin, gunny, woven bags and openly keeping. The reason for minimum content in markin, gunny, woven bags and openly keeping may be due to the more moisture absorbing capacity of these bags which leads the reduction in the oil content. The study is also supported by Sinh (1999) who reported packing wise bio-deterioration of phytoconstituents that was found high in paper and cloth packings. Highest microbial load was found in gunny bags since gunny bags are made of jute fibers which are of botanical origin cellulytic compounds and are hygroscopic in nature. Minimum load was recorded in polythene packing because polythene did not permit the growth of micro-organisms and found much more effective in controlling the loss of the phytoconstituents. Masand et al., (2014) reported that there are no guidelines for proper storage of herbal raw materials till date. It is only the proper handling, packaging and storage of herbs which can preserve the safety, efficacy and quality of herbs. Thillaivanan and Samraj (2014) reported that the physical factors such as air (oxygen), humidity, light, and temperature can bring about deterioration of plant materials directly or indirectly.

\section{Conclusion}

It can be concluded from the study that Malkangni seeds should be washed in water and dried in sun for $24 \mathrm{hrs}$. before the storage. Moreover, high density polythene (HDPE) bags, $4-5^{\circ} \mathrm{C}$ temperature and duration of six months were found optimum for storage of Malkangni seeds in term of oil content. These findings can be utilized by the traders and other dependent communities for the proper storage of the seeds for fetching better price in the market and thus, will help in their livelihood improvement.

\section{Acknowledgement}

Author pays his gratefulness to the Director of the Institute for providing necessary facilities to conduct the research work. The financial support from ICFRE project (ID-206) is greatly acknowledged.

\section{References}

Anonymous. 2020. https://www.nmpb.nic.in/medicinal_list.

Ansari, S.H. 2011. Essentials of Pharmacognosy. Birla publications pvt ltd, 10-16.

Downs, S. and Compton, E. 1955. Crop drying with heated air. Agricultural Engineering, 36: 90-92.

Gatinode, B.B., Raiker, K.P., Shroff, F.N. and Patel, J.R. 1957. Pharmacological studies with malkanguni, an indigenous tranquilizing drug (preliminary report). Current Practice, 1: 619-621.

Hakim, R.A. 1964. A trial report on Malkangni oil with other indigenous drugs in the treatment of psychiatric cases, 7778. In: Gujrath State Branch, IMA Med Bulletin.

Jadhav, R.B. and Patwardhan, B. 2003. Anti-anxiety activity of Celastrus paniculatus seeds. Indian Journal of Natural Products, 19(3): 16-19.

Kalt, W., Forney, F.C., Martin, A. and Prior, R.L. 1999. Antioxidant capacity, vitamin C, phenolics, and anthocyanins after fresh storage of small fruits. Journal of Agricultural and Food Chemistry, 47: 4638-4644. 


\section{Standardization of processing and storage techniques}

Kamboj, A. 2012. Analytical Evaluation of Herbal Drugs. In: Vallisuta, O. (Ed), Drug Discovery Research in Pharmacognosy. 1st ed. Rijeka, Croatia: Tech Publication

Karlund, A., Moor, A., Sandell, M. and Karjalainen, R.O. 2014. The Impact of harvesting, storage and processing factors on health-promoting phytochemicals in berries and fruits. Processes, 2: 596-624.

Kokate, C.K. and Gokhale, S.B. 2004. Pharmacognosy. Niraliprakashan, Delhi.

Masand, S., Madan, S. and Balian, S.K. 2014. Modern concept of storage and packaging of raw herbs used in Ayurveda. International Journal of Research in Ayurveda and Pharmacy, 5(2): 242-245.

Nadkarni, A.K. 1976. In: Nadkarni's Indian Materia Medica, 1-296, Popular Prakashan, Bombay, India.

Nalini, K., Aroor, A.R., Kumar, K.B. and Rao, A. 1986. Studies on biogenic amines and metabolites in mentally retarded children on Celastrus oil therapy. Alternative Medicine, 1: 355-360.

Singh, N. 2008. Processing techniques of NWFPs of Chhattisgarh TBOs - Madhuca latifolia, Shorea obusta, Schleichera oleosa, Pongamia pinnata and Buchanania lanzan. A project report submitted to TFRI, Jabalpur.

Sinh, M. 1999. Effect of gamma radiation and different packings used for storage of the drug bahera fruit (Terminalia bellerica Roxb.) on microflora population (fungi, pathogenic bacterial sp. \& spc) and on the phytoconstituents (protein and tannin). Ancient Science of Life, 18 (3\&4): $218-227$.

Tanko, H., Carrier, D.J., Duan, L. and Clausen, E. 2005. Pre and post-harvest processing of medicinal plants. Plant Genetic Resources, 1-11.

Thillaivanan, S. and Samraj, K. 2014. Challenges, Constraints and Opportunities in Herbal Medicines - A Review. International Journal of Herbal Medicine, 2(1): 21-24. 